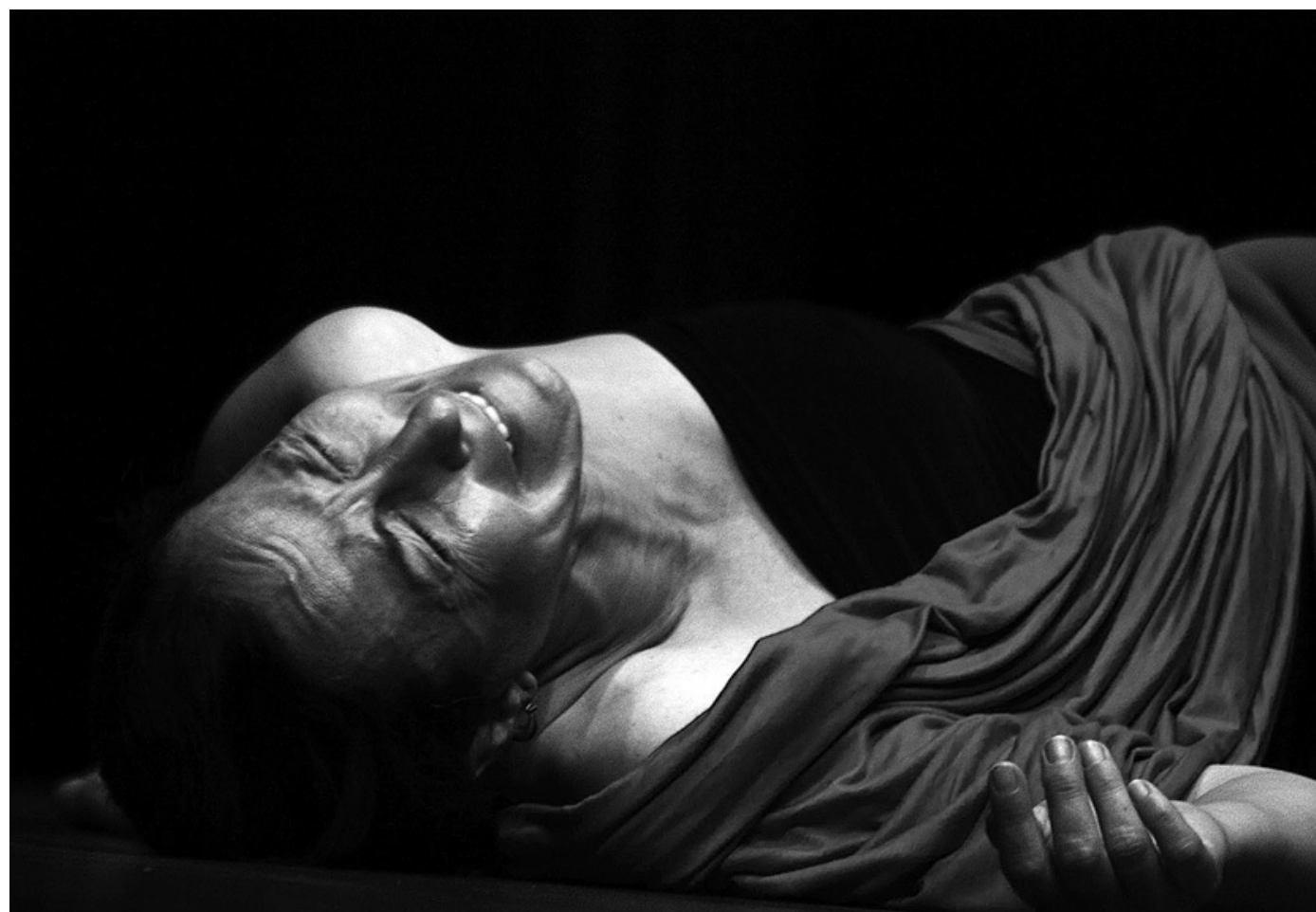

\title{
Tradução, adaptação e reescrita 0 cante e o pranto do Alentejo
}

\section{Sebastiana Fadda}

1. Estudos de Tradução: uma vocação interdisciplinar Um dos ensaios de referência em matéria de Estudos de Tradução enquanto disciplina institucionalizada e aceite nas academias, Translation Studies (1980, 1. ${ }^{\text {a }}$ ed.; 2003, 3. ${ }^{\text {a }}$ ed.), de autoria de Susan Bassnett, encontra-se disponivel em português com o título Estudos de tradução (2003). A autora, no prefácio à edição revista de 1991, atreve-se a lançar um desafio aos colegas comparatistas fazendo uma afirmação provocatória: os Estudos de Tradução não deveriam ser considerados um ramo da Literatura Comparada, mas antes o contrário seria mais exacto, uma vez que os primeiros, pela sua abrangência, deveriam ser considerados a disciplina principal, enquanto a segunda, que retira o seu alimento da literatura traduzida, não passaria de um dos seus importantes ramos. Para reforçar a sua posição, Bassnett refere o exemplo da Semiótica, surgida no âmbito da Linguistica, e a seguir reposicionada num lugar superior na sua relação hierárquica com a ciência que a teria gerado.

Parece evidentemente discutivel e pouco fundamentada a asserção da autora, pois, por exemplo, no caso de comparatistas multilingues a tradução é feita pelos próprios no acto da simples leitura. Compreende-se, todavia, que a finalidade era a de chamar a atenção para uma disciplina que na altura estava a tentar marcar o seu território e a fortalecer a sua autonomia. Era, ainda, uma forma de medir forças com o sistema académico, em que estava a inserir-

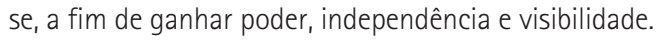

De resto, o que se depreende da posição de outro ilustre teórico, André Lefevere (1995), é que a tradução, detestada ou tolerada pelos comparatistas, teve de proceder, através da criação dos Estudos de Tradução, a uma espécie de assassínio simbólico do pai para conquistar um espaço próprio, o que possibilitaria a abolição da hierarquia mantida até hoje.

Também João Barrento, como Susan Bassnett, se questiona acerca da relação entre Literatura Comparada e Tradutologia, embora noutros moldes e sem pretender defender a primazia de nenhuma das disciplinas em causa. Propõe a este propósito três hipóteses: a primeira seria a articulação entre tradutologia e literatura comparada, considerando-se ambas disciplinas autónomas que esclarecem conjuntamente as várias facetas do fenómeno literário; a segunda possibilidade contempla o facto de a tradutologia ser uma disciplina acessória, ao serviço do comparativismo, a fim de integrar e complementar a sua metodologia aplicada; a terceira admite que os Estudos de Tradução sejam um "'objecto' privilegiado da comparatística" (cf. Barrento 2002: 65-73). Estas hipóteses levantariam outros problemas, sendo o mais relevante 0 de vislumbrar se a literatura comparada tem uma metodologia própria ou se antes não terá servido como receptáculo de vários métodos provenientes dos estudos literários, alargando os seus objectos de análise e tornandose numa disciplina teorética que profere metadiscursos. Trata-se de uma mera constatação, não de uma afirmação 
valorativa em sentido depreciativo, pois a própria teoria da literatura tem-se alimentado com a interdisciplinaridade. Pelo contrário, os limites dos Estudos de Tradução comprometeriam a sua própria eficácia e operatividade:

Não descortino na chamada "tradutologia", e muito menos na por vezes demasiado ambiciosa "critica da tradução", nem autonomia metodológica suficiente (enfeudadas como estão, as mais das vezes, a uma microlinguistica do texto), nem instrumentário conceptual que thes permita aperceberem-se dos mecanismos de fundo dos processos de transposição de um texto literário e descrevê-lo (...) Precisamos, então, de uma teoria da tradução literária. Acontece que a minha "teoria prática" da tradução literária poderá parecer, à primeira vista, incompativel com a desejada articulação com os estudos literários comparados. (Ibid:: 68-69)

Para lá do que pedem estes protocolos de leitura sobre articulações possiveis entre campos científicos que pensam a literatura, os Estudos de Tradução integram hoje uma componente cultural, e a perspectiva histórica - de que não prescinde - vem avaliando a sua evolução e os sentidos outros que vai incorporando. A disciplina é, por estas e outras razões, vista como complexa e interdisciplinar, tendo expandido os seus objectivos a ponto de irem para lá da abordagem científica do acto tradutório, incorporando também a valorização do profissionalismo do tradutor. Por outro lado, o texto literário traduzido é também analisado e avaliado, não como mero subproduto cultural ou sucedâneo da literatura original, antes merecendo atenção enquanto objecto literário a que se não recusa dignidade.

É o que se defende no prefácio à terceira edição de Translation Studies, onde são retomados alguns dos tópicos desenvolvidos no prefácio à edição anterior (de 1991), dando-se conta do interesse e autonomia crescentes que marcaram a nova disciplina nas décadas de 80 e 90 do século XX. Passara de um tempo em que o ramo mais desenvolvido era o da história da tradução, até aos anos 70, para uma atenção virada para as novas tecnologias, considerando as vantagens que delas podiam advir para a tradução automática. E não deixara de desenvolver o âmbito da sua reflexão, apurar o aparelho conceptual e metodologias até se propor como matéria interdisciplinar dotada de autonomia, visibilidade própria e, sobretudo, em franca expansão a nível mundial e com uma visão bem definida da figura do tradutor: por um lado, seria um mediador criativo que permite a sobrevivência dos textos e a divulgação cultural; por outro lado, não está isento da suspeita de alguns relativamente a uma tarefa que pode facilmente ceder a manipulações de vário alcance e responsabilidade, tanto de ordem pessoal, como por parte dos poderes constituídos. Uma terceira perspectiva depreende-se da posição de Umberto Eco, que contempla a tradução enquanto processo de negociação entre textos e culturas (Eco 2003).
Tinha-se, então, finalmente ultrapassado o discurso de "perdas" e "infidelidades", visando antes "compreender as mudanças de ênfase operadas durante a transferência de textos de um sistema literário para outro" (Bassnett 2003: 12). Nesse sentido, a tradução deixara de ser um reflexo do original, para a ela se ligar o conceito de refracção, o que implicava a descodificação e recodificação de um sistema complexo noutro sistema igualmente complexo, onde poderão caber interrogações sobre reescrita e manipulação, implícitas em qualquer processo tradutório.

Ainda na introdução ao seu livro, Bassnett acrescenta que a designação "Estudos de Tradução" data de 1978 e respondia a uma sugestão de André Lefevere. Passou desde então a indicar a disciplina que se ocupa "dos problemas levantados pela produção e descrição de traduções" (apud ibid: 19). Termos como Língua de Partida e Língua de Chegada passaram a remeter respectivamente para o texto original e para o texto traduzido, considerando-se o processo como uma actividade virada para a devolução de sentidos do primeiro, sem deturpação da estrutura do segundo.

Constituida a disciplina, nomeada e reportada a um objecto de estudo, faltava avaliar o acto tradutório: uma arte (substantivo enobrecedor mas com reservas)? Uma ciência (substantivo que Ihe reduziria a componente criativa)? Ou um ofício (substantivo algo depreciativo que apontaria para um exercício meramente tecnicista)? Talvez a resposta mais satisfatória possa conjugar esses três componentes e a tradução deva ser considerada como partilhando um pouco de tudo isso: uma arte, pois implica uma componente criativa; uma ciência, pois é possivel proceder a uma sistematização metodológica; um ofício, em que a parte artesanal da tarefa não pode ser ignorada.

Por integrar tão diversos objectos, práticas e perspectivas, Susan Bassnett distingue nos Estudos de Tradução quatro áreas gerais: duas "orientadas para o produto", por incidir no Texto de Chegada, duas "orientadas para o processo", por incidir no que acontece durante a tradução: a primeira categoria contemplaria a História da Tradução, que seria parte integrante da História da Literatura; a segunda categoria contemplaria a Tradução na Cultura da Lingua de Chegada, pois haveria interacção e influências reciprocas; a terceira categoria contemplaria a Tradução e a Linguística, pois numa análise contrastiva dos vários niveis das línguas podem surgir soluções inesperadas; a quarta categoria contemplaria a Tradução e a Poética e incluiria a teoria e a prática da tradução literária no seu sentido mais abrangente (cf. ibid.: 29-30). Haveria outra questão a não subestimar, a da avaliação, quer por parte dos próprios tradutores, quer por parte da crítica literária: os primeiros podem querer melhorar traduções já existentes ou o próprio texto de partida, o que implica a formulação de um juizo de valor sobre os outros objectos com os quais entram em contacto; a segunda, no caso de dominar a língua de partida e a de 


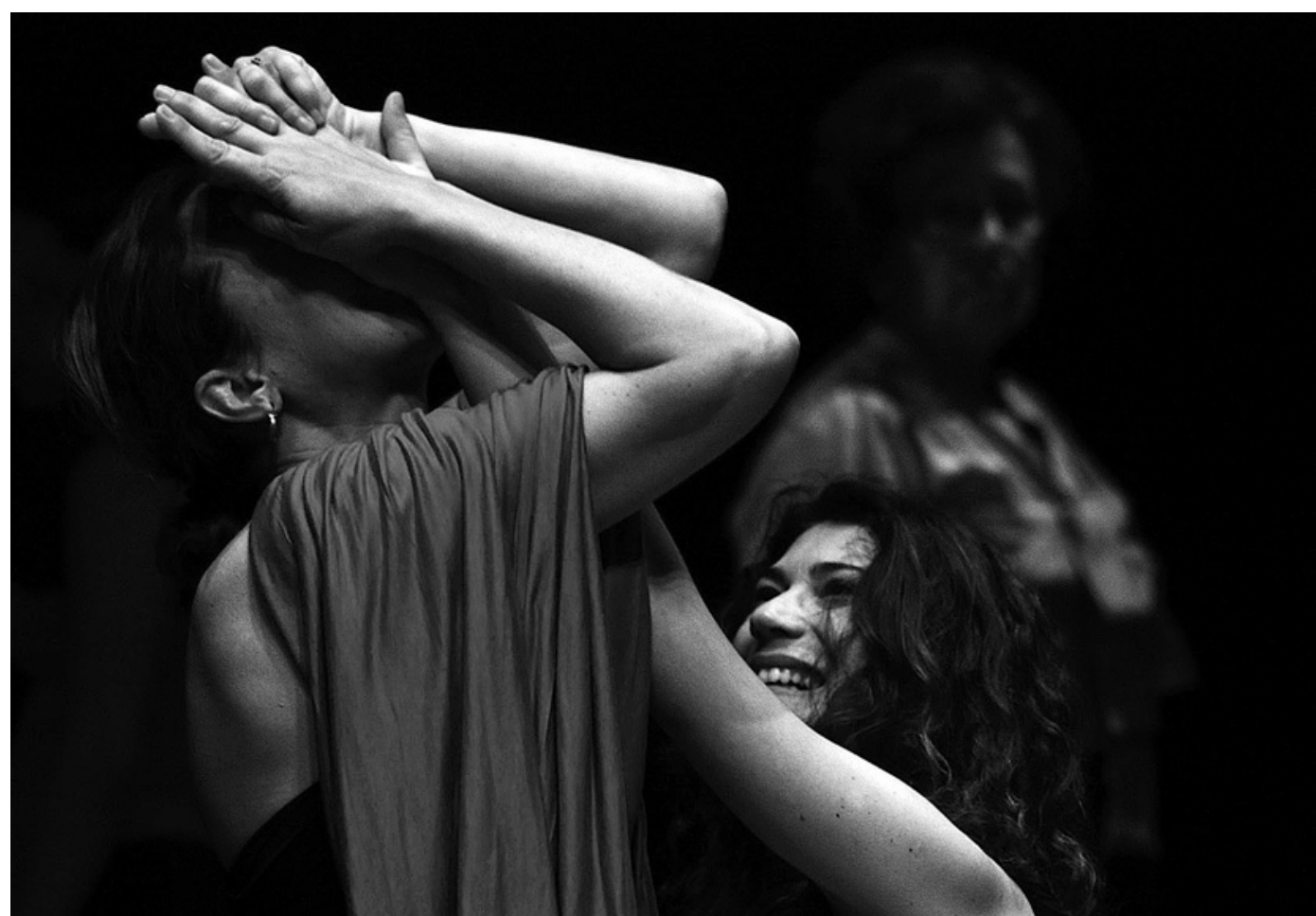

chegada, tem a tendência a proceder a uma avaliação valorativa redutora, que implicaria a proximidade entre o texto de chegada e o texto de partida, ou então, no caso de não dominar a língua de partida, será tentada a avaliar a tradução como se fosse um original. Se a avaliação dá poder ao avaliador, que assim se coloca numa posição de superioridade por vestir a beca do juiz, é um facto indesmentivel que os critérios de avaliação mudam conforme os tempos e os avaliadores, não havendo normas, regras ou critérios universalmente válidos para a avaliação de textos, originais ou traduzidos. Mais: não há texto ou tradução que se possa considerar definitivo/a, pelo que todos estão sujeitos a possiveis alterações e revisões. Nem se pode considerar a tradução alheada de um contexto mais alargado, pois a aplicação aos Estudos de Tradução das teorias ligadas à Semiótica tem sido fundamental, determinando a consideração da tradução como um acto que ultrapassa a Linguistica (logo, a transmissão de sentidos pela permuta de signos linguísticos), para se integrar em sistemas mais complexos, ou seja, uma rede de sistemas também extra-linguísticos, literários, culturais, sociais e ideológicos que interagem uns com os outros.

Nesse sentido, é bem sugestiva a metáfora usada por João Barrento na cartografia conceptual que desenha em 0 poço de Babel e que procura justamente referir esta rede de relações. Trata-se da "ponte" que, aplicada ao acto tradutório, significa o estabelecimento de um contacto, a abertura de uma via de passagem entre línguas, culturas e literaturas. Deve-se ao respeitado germanista, com orientação descritiva e não valorativa, 0 reconhecimento do importante papel desempenhado pela tradução na formação ou na revitalização de várias literaturas nacionais frágeis, periféricas ou em momentos de crise, pois há um factor que permite que isso aconteça: o reconhecimento de si na alteridade. Mas ao mesmo tempo acontece outro fenómeno fundamental: na alteridade que se oferece como alimento, tem lugar aquilo que Walter Benjamin chamava "a sobrevivência das obras" (apud Barrento 2002: 158). Trata-se de um dúplice movimento de re-vitalização, no agente e no objecto. E se, regressando à metáfora da ponte, "traduzir é interrogar o outro para trazer a distância à proximidade do próprio, através da escuta da voz desse outro" (ibid.: 208), o facto de preencher distâncias e re-conhecer-se no - graças e através do - outro, remete para um acto de amor, não desprovido de uma dimensão pedagógica implícita. Com Heidegger, a quem se deve essencialmente o conceito anterior, poderíamos dizer que:

Traduzir é acima de tudo um despertar, uma clarificação, um desabrochar da lingua própria com a ajuda da confrontação com a lingua-outra. Tecnicamente, a tradução será a substituição da língua estrangeira pela própria, ou vice-versa. Do ponto de vista de uma sua tomada de consciência da sua dimensão histórica, traduzir representa um relacionamento produtivo com a lingua estrangeira, tendo em vista a apropriação da própria. (Heidegger apud ibid.: 213)

Deste modo, verifica-se um dúplice movimento, nas duas direcções: ao encontro da língua, da cultura e do texto de partida (do outro), e ao encontro da língua, da cultura e do texto de chegada (de si próprio). Com João Barrento pode-se ainda acrescentar que toda a tradução é um acto "filo-lógico", ou seja um comentário, uma interpretação, que inclui um acto hermenêutico operado por um "filólogo", etimologicamente um amante da palavra.

2. Tradução e reescrita: à procura do texto perdido Com base nas premissas lançadas acima e em sintonia com um conceito mais amplo da função do tradutor literário, este pode ser considerado um reescritor, na medida em que a sua tentativa de devolver a letra e o espírito do original, nunca sendo neutra nem inocente, gera um novo texto que resulta da sua bagagem de conhecimentos e competências linguísticas, literárias e 


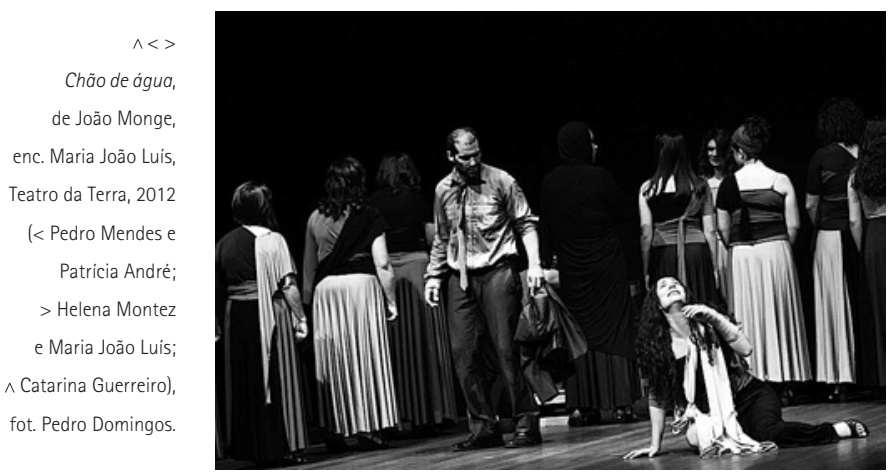

culturais, bem como das estratégias e negociações praticadas.

No caso da tradução de teatro, acrescenta-se um factor decisivo que permite que a dimensão literária que o texto dramático também possui seja projectada para a dimensão cénica, dele extraindo-se a sua teatralidade, cuja essência é definida por Roland Barthes como segue:

O que é a teatralidade? É o teatro menos o texto, é uma rede de signos e sensações que se constrói a partir da escrita, é essa espécie de percepção ecuménica dos artificios sensuais, gestos, tons, distâncias, substâncias, luzes, que submerge o texto sob a plenitude da sua

linguagem exterior. (Barthes apud Pavis 2002: 358, tradução minha)

A faculdade inscrita na letra, que permite ser convertida em matéria concreta através da fala e do gesto, constitui a especificidade do texto dramático que não pode ser ignorada pelo tradutor de teatro: texto e representação estão "indissoluvelmente ligados" (Bassnett 2003: 191). A língua é apenas um dos signos que concorrem para a criação daquele sistema complexo que é o espectáculo, dai que a sua transformação em fala, integrada num determinado contexto extralinguistico, em articulação com outras partituras sígnicas, faz com que a partitura monológica e/ou dialogal com os seus tons, ritmos e pausas transmita sentidos adicionais, dilatando os seus ecos e reverberações.

Pela sua produtividade na compreensão e descrição dos fenómenos literários, é oportuno convocar aqui a teoria dos polissistemas, elaborada por Itamar Even-Zohar e Gideon Toury, da Universidade de Tel Aviv, a partir dos anos Setenta e com base nas ideias do formalista russo Yuri Tynyanov, que afirmava que a literatura devia ser estudada tendo em conta as suas relações com os demais sistemas. Todo o texto possui a sua determinação histórica encontra-se inscrito em sistemas caracterizados por
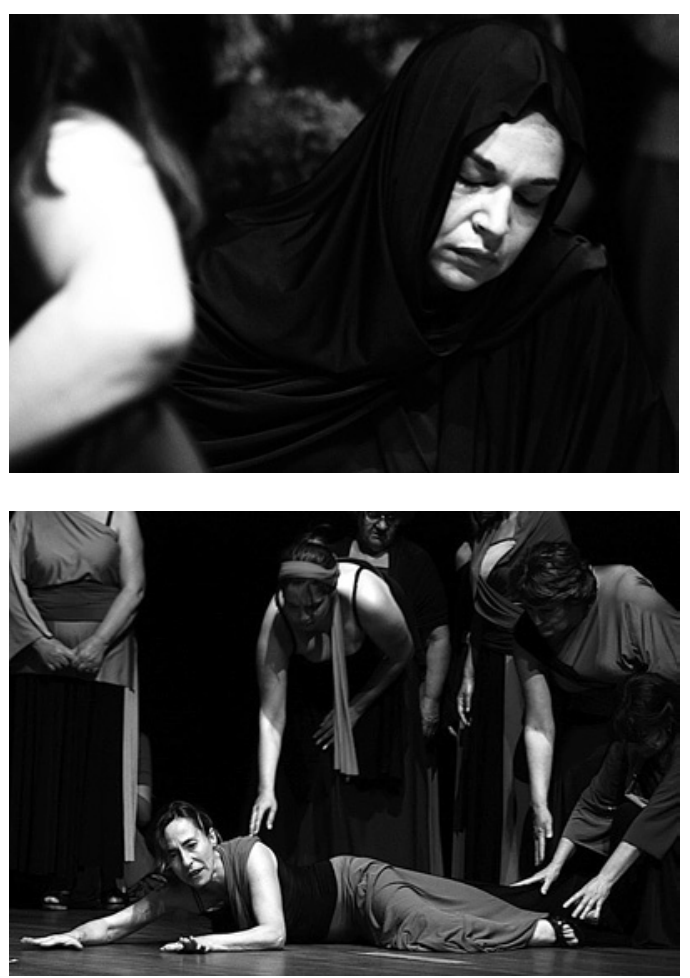

hierarquias, determinadas com base nas relações com as normas e modelos dominantes ou dominados, nacionais ou internacionais, em que os micro e macrocosmos são interpretados considerando elementos fundamentais.

Como reconhecido por Susan Bassnett, e já referido mesmo que de passagem, ao traduzir não se verte simplesmente duma língua para outra, mas dum sistema literário e cultural para outro. Ampliando o campo de observação do texto para os contextos que o determinaram e em que se insere, bem como as relações de força entre as duas culturas envolvidas, dificil será subtrair-se à díade que define as estratégias de tradução como domesticadoras (que levam o autor ao público, dominando a cultura de chegada) ou distanciadoras (que levam o público ao autor, dominando a cultura de partida). As "belles infidèles", como eram chamadas no século XVII as traduções francesas dos clássicos greco-latinos, revisitados e moldados aos tempos e gostos contemporâneos, eram irmãs de muito teatro, sobretudo de cordel e incluindo autores coevos, que por estas latitudes foi representado "adaptado ao gosto portuguez", justificando-se na expressão italiana "traduttore traditore" um facto consumado, natural e inevitável. Adaptações, glosas, versões livres, revisitações, ao mesmo tempo que deixariam subentender ou reforçar o mito da intraduzibilidade, legitimariam a sobreposição e primazia do sistema de chegada sobre o sistema de partida, ou então a acusação de desvio do original. Em contrapartida, a tradução norteada pela estratégia da fidelidade à letra correria o risco de ser condenada pela sua irrepresentabilidade ou de ser recebida como estranha num sistema de chegada com normas diferentes das do original:

Por exemplo, o pesado pedantismo de muitas versões inglesas de Racine constitui um testemunho acabado do erro da literalidade excessiva, mas o problema de definir "liberdade" na tradução de teatro é mais dificil de discernir. (Ibid.: 194) 


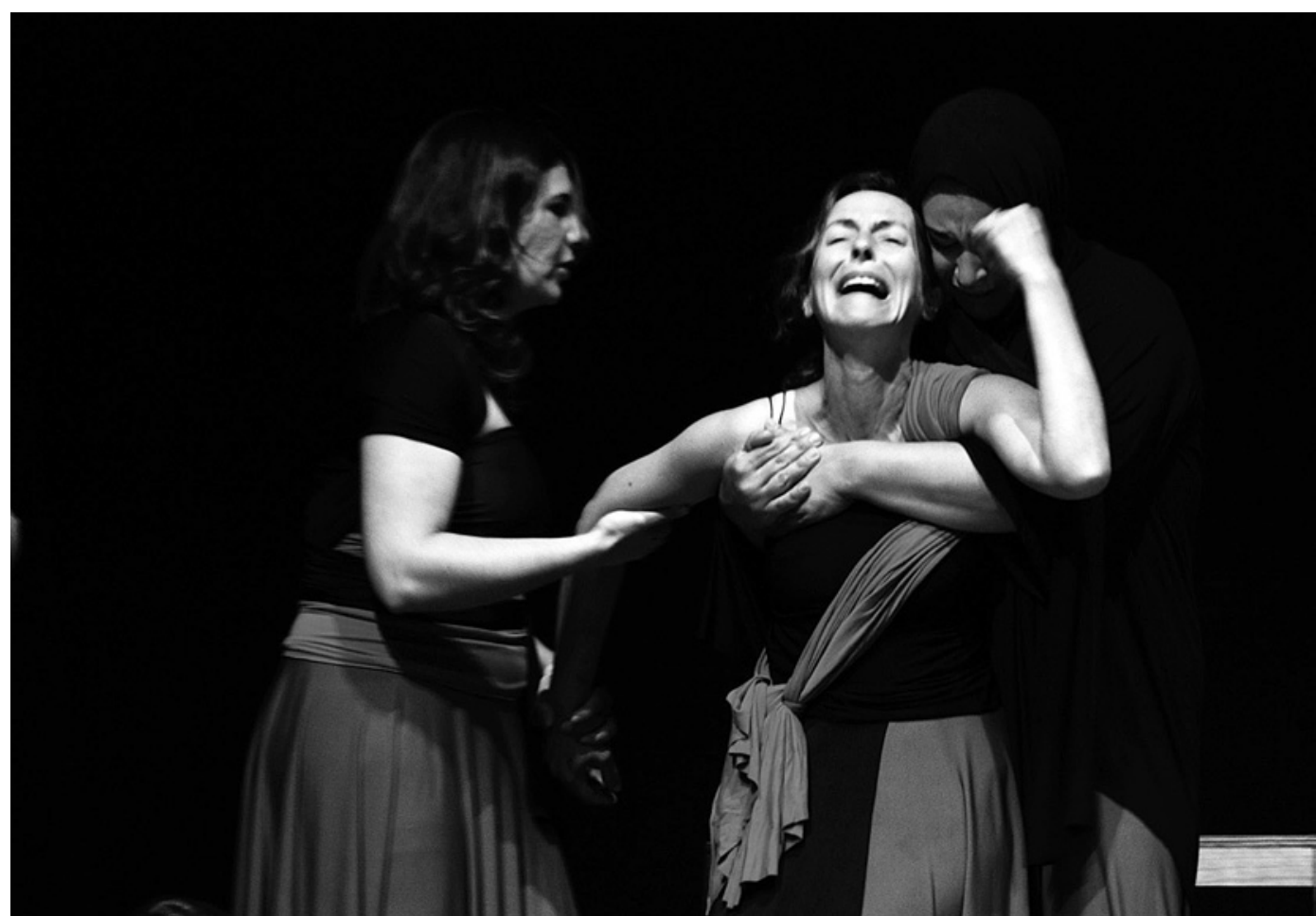

A titulo exemplificativo Susan Bassnett examina três versões inglesas da Fedra para demonstrar a dificuldade em se traduzirem estruturas métricas e gestuais, mas também sistemas para-linguisticos e referenciais capazes de transmitirem intenções e relações subjacentes às falas e ao texto.

No caso da estreia de Andrómaca em 1674, o tradutor John Crowne aduziu o seu fracasso à falta de empatia do público com o gosto e a afectação franceses, mas quando mais tarde foi apresentada com o titulo The Distres't Mother (com edição em 1712), numa adaptação de Ambrose Philips, que cortou, integrou e alterou a seu gosto - isto é, ao gosto do público e dos modelos londrinos -, o êxito foi retumbante: "Philips estabeleceu uma 'hierarquia de correspondências', em que o texto é encarado como um elemento adaptável na produção do espectáculo teatral." (Ibid.: 199).

Bassnett observa ainda outro objecto que utilizou uma estratégia análoga: Phedra Britannica, assinada pelo poeta e dramaturgo Tony Harrison. Aqui as fronteiras entre a adaptação, a versão livre e a recriação original resultam esbatidas pela transferência da acção em contexto colonial, sendo as duas ordens e sistemas em conflito os ingleses e os indianos. Apesar das alterações, a estrutura versificatória, os equilibrios, as relações e linhas de força gerados por Harrison no novo texto aproximá-lo-iam ao original raciniano, justificando as suas decisões como sendo orientadas para a representação.

0 verbo traduzir, do latim traducere (trans ["para além] + ducere ["conduzir / levar], literalmente "fazer passar / levar / conduzir para além"), contém na sua etimologia esses mesmos sentidos: leva-se alguém dum lugar para outro ou uma obra duma língua para outra. Há porém outro aspecto da tradução - de teatro mas não só - que importa salientar: para além de ter a capacidade de alimentar de forma directa, pela modalidade propriamente dita, o repertório disponivel no sistema de chegada, pode ainda contribuir de forma indirecta, pelo impulso desencadeado na criação original naquele mesmo sistema. Deste modo Anouilh e Brecht (via Hölderlin) foram induzidos a trazer o mito de Antígona, de que Sófocles foi o porta-voz trágico por excelência, para o século XX, quando tão oportuna se tornava a resistência da protagonista contra a cegueira dos poderes totalitários. Algumas das ressonâncias em português deveram-se a António Sérgio, Júlio Dantas, António Pedro, Eduarda Dionisio e Hélia Correia, entre outros, tendo havido um poema de Sophia de Mello Breyner Andresen, Catarina Eufémia (1972), em que a poetisa "aproxima a atitude intrépida de Catarina Eufémia da de Antígona, duas mulheres que ousaram 'fazer frente' e personificaram a 'inocência frontal' que não recuou na defesa da justiça" (Morais 2001: 163). E porque, como afirmado no último verso do poema, "a busca de justiça continua", em homenagem à memória de Catarina Eufémia, João Monge chamou Catarina à protagonista do seu Chão de água, peça que trouxe Euripides e as suas Troianas até nós, para a nossa geografia e o nosso tempo.

\section{Lágrimas geminadas: das chamas de Tróia às} águas do Alentejo

A tragédia As troianas foi apresentada nas Grandes Dionísias atenienses de 415 e encerrava uma trilogia euripideana dedicada aos míticos acontecimentos relacionados com a guerra de Tróia. 0 reconhecido realismo de Eurípides como sendo um dos traços distintivos da sua obra, quando comparada com os seus pares e antecessores - Ésquilo e Sófocles - dá nesta peça soberbas provas de rara atenção aos sentimentos e sofrimentos humanos, especialmente das mulheres, aqui retratadas no seu desespero depois da queda de Tróia, vencida pelos gregos, aos quais serão destinadas como troféus de guerra. No prólogo surgem Atenas e Poséidon para recapitular muito sucintamente os antecedentes e as consequências da 
disputa entre os dois povos em luta, mas cedo desaparecem para deixar lugar às vicissitudes humanas. Embora algum relevo seja dado à figura do mensageiro encarregado de comunicar as decisões dos gregos, são as mulheres as grandes protagonistas dum texto em que a palavra é mero suporte para uma longa, imensa e dilacerada lamentação, onde não há verbo ou gesto capaz de nomear ou transmitir a dor infinita pela perda dos entes amados e de outros bens maiores como a liberdade e o lar. Por isso Hécuba é emblema da mulher universal por ser não apenas rainha, mas também mãe que, pelo seu estatuto social e pelo relevo que o dramaturgo Ihe atribui, dignifica e representa toda a força e fragilidade de todas as mulheres. Incluindo as mulheres dos vencedores, deixadas à espera e à guarda de casas - às quais nem todos irão regressar -, e cujas lágrimas têm a mesma cor e o mesmo sabor das que sulcam o rosto das vencidas. Vítimas da injustiça e da ambição masculina, são rainhas no e do sofrimento. Mas há outras pistas de leitura. Escreveu Maria Helena da Rocha Pereira na introdução à sua versão da peça:

Desde considerá-la uma tragédia menor a encontrar nela uma mensagem profunda e apelativa como poucas, uma cruzada pacifista ou uma obra de propaganda politica, tudo tem sido dito sobre As troianas. (Pereira in Euripides 1996: 19)

Num tempo e num espaço em que o teatro era de e para a polis, o facto de ela ter sido escrita numa trégua da longa guerra entre atenienses e espartanos conhecida como a guerra do Peloponeso - entre o massacre e saque de Milos (416 a.C.) e em vésperas da expedição contra Siracusa (415-413 a.C.) -, seria ingénuo considerar casual o conteúdo político e a condenação implícita das manobras expansionistas de Atenas. Portanto, por um lado, a perspectiva e a manifesta compaixão do autor são dirigidas para as vitimas indirectas, como que invisiveis aos olhares dos guerreiros, numa sociedade gerida pelo poder masculino e em que as mulheres eram consideradas inferiores aos homens, sendo sujeitas ao seu domínio mesmo quando beneficiavam do estatuto de cidadãs livres. Por outro lado, o autor transcende o mito para o situar historicamente e tomar uma posição política, já que surpreenderia que um poeta dramático ignorasse ou não tivesse plena consciência do alcance e das consequências que o seu ponto de vista tão definido e definitivo, embrulhado nas roupagens vibrantes da linguagem poética - apresentado numa festa tão aguardada e participada como a que previa os concursos dramáticos - iria ter junto do público.

Já no século XX, regista-se uma apropriação significativa dessa linguagem e dessa posição na adaptação feita por Jean-Paul Sartre de Les troyennes (1965), cuja relação com a actualidade, característica imprescindivel do teatro original do filósofo existencialista, prendia-se com a guerra de independência argelina, visando porém a condenação da guerra e da violência tout court. Esta adaptação foi levada à cena em 2009 pelo jovem grupo
Point d'Orgue, de Montreal, numa encenação de LouisKarl Tremblay, que resolveu introduzir um aspecto controverso estritamente ligado ao contexto canadiano: os gregos falavam em inglês e as mulheres troianas em francês. Numa entrevista o encenador afirmou o que segue:

Se se quiser ver uma tomada de posição sobre o Quebeque na minha encenação, ela encontra-se na língua do inimigo, que não é grego, mas inglês. Pode ser um pouco rude dito assim, mas isso não é para contar que os nossos inimigos são os canadianos ingleses. Não quero fazer um espectáculo nacionalista, mas talvez um espectáculo sobre a lingua e a identidade, questões actuais que me preocupam. (Tremblay apud Couture 2009, t.m.)

0 encenador queria que os espectadores inferissem que a ameaça a pairar sobre a preservação identitária da comunidade francófona do Quebeque vinha da comunidade anglófona ou, mais em general, do imperialismo americano. Todavia o efeito terá tido impacto reduzido, por ser um recurso "moins hereux" - que terá dificultado a compreensão por quem não era bilingue (Olivier 2009).

Outra maturidade, finura e eficácia respiram no texto de João Monge, cuja adequação ao contexto e à actualidade portuguesa faz dele uma (re)criação original a partir do molde clássico. Trata-se dum perfeito exemplo de reconhecimento do poder e do valor do outro para reflectir e devolver imagens de si: ao mesmo tempo que se admite a autoridade da fonte / ponte transnacional e intemporal, procura-se a sua renovação através do exercicio e afirmação da autonomia autoral. Pela via da poesia e pela arma do teatro chega-se a interpelar a realidade que estimulou uma escrita que a essa mesma realidade se destina e entrega.

Chão de água foi produzido pelo Teatro da Terra, companhia fundada em Ponte de Sor por Maria João Luís, encenadora e intérprete principal do espectáculo, concebido com as intervenções do agrupamento Coral Polifónico daquela vila, e entendido como um teatro, literalmente, da e para a terra: teatro e terra de resistência, redutos, territórios geográficos, culturais e humanos nas margens da sociedade de consumo e não resignados ao silenciamento. 0 teatro de Eurípides tinha com a cidade os mesmos laços e integração que o Teatro da Terra tem com o Alentejo. É decerto um paralelo reduzido em termos de escala, mas não no eco capaz de produzir.

João Monge criou um sistema de equivalências sólido claro e coerente, através do qual actualiza a fonte, dela mantendo os traços antigos da linguagem elevada, sugestiva, metafórica e poética. A luta travada entre os dois povos clássicos é agora travada entre a civilização capitalista e a civilização humanista, entre um sentido desviante do conceito de modernidade, que rima com a alienação, e um sentido enobrecedor do conceito de tradição, que rima com a autenticidade. Tróia, vencida pelos gregos e em chamas, encontra-se transposta para o Alentejo submerso pelas águas das barragens, aqui 


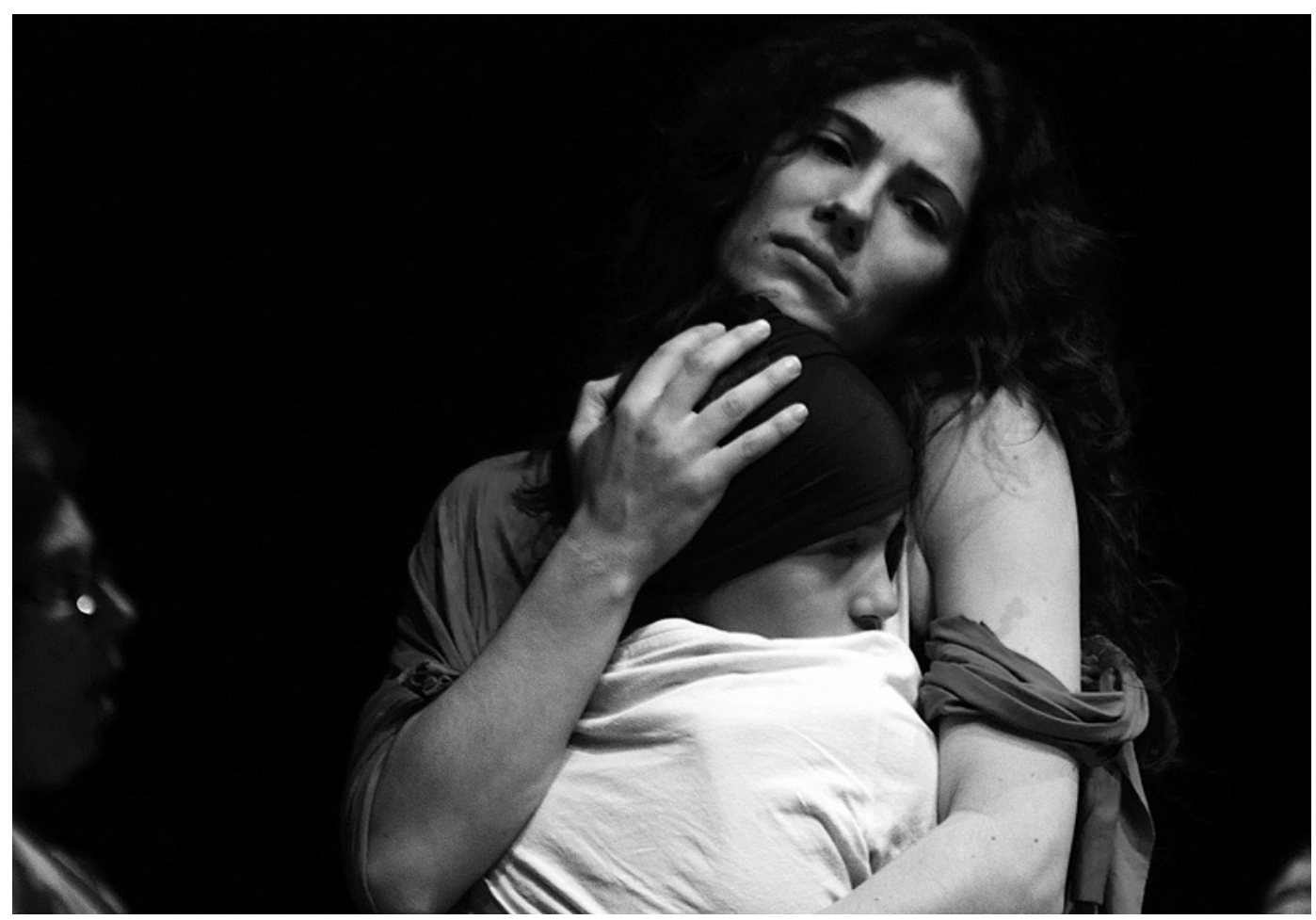

chamado Mar de Soberba por ter prometido prosperidade e ter explorado ulteriormente uma comunidade - pobre de matéria, mas não de alma. Os troianos são os camponeses da periferia alentejana e os gregos os citadinos do centro dominador. As mulheres escravas destinadas à casa dos vencedores terão agora como perspectiva um futuro feito de alienação urbana. Poséidon é o Senhor das Águas e Atena é a Senhora da Sabedoria. Às mulheres troianas e à sua civilização sobrepõem-se agora as Mulheres da Luz e os seus valores, guardas dos segredos e saberes duma vida significativa. Outras correspondências são a identificação de Hécuba em Catarina, Helena em Luzia e Menelau no Rei da Cidade (a sua relação, de conjugal passa a filial e paternal), Cassandra em Laura, Andrómaca em Maria da Luz, Taltíbio em Porta-voz, Astianacte em Menino. Ao canto coral da tragédia clássica sobrepõe-se o cante tradicional alentejano, expressão representativa duma identidade ancestral e irrenunciável. 0 Mar Fervente de indignação dos homens, afogados pela exploração da Cidade, tornar-se-á um Mar da Serenidade pela imolação das mulheres, que nele procuram o abrigo apto para preservar o direito à livre escolha. Ao recusar o futuro traçado contra as suas vontades, reunir-se-ão com os seus amados, pagando pela conservação duma integridade identitária o preço da vida, acertando assim as contas com a terra, a que é dedicado o canto final, entoado à capela por uma voz masculina:

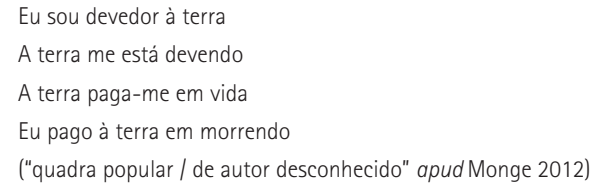

0 resultado cénico, num espaço despojado que amplifica o poder evocativo da palavra e do cante, reenviando para realidades agrestes, mas também fundamentais, é de grande intensidade. Um projecto artístico militante que se contrapõe às barbaridades e saqueios da sociedade actual, alimentando o repertório contemporâneo pela reconfiguração duma obra clássica cujos temas falam aos homens e mulheres de sempre, sobre o que deveras conta. Rejeitado todo artifício, fica a arte a dialogar com a vida. Uma arte que vibra e estremece no belissimo cante alentejano, que ainda hoje continua a comover e a perturbar.

\section{Referências bibliográficas}

BARRENTO, João (2002), 0 poço de Babel: Para uma poética da tradução literária,

$$
\text { Lisboa, Relógio d'Água. }
$$

BASSNET, Susan (2003), Estudos de tradução. Fundamentos de uma disciplina, trad. Vivina de Campos Fiqueiredo, revisão de Ana Maria Chaves, Lisboa, Fundação Calouste Gulbenkian.

COUTURE, Philippe (2009), Lutter pour sa survie, 1 de Outubro; artigo consultado in <http://voir.ca/fiches/scene/troyennes-les/> [data de acesso: 3 de Maio de 2013].

ECO, Umberto (2003), Dire quasi la stessa cosa. Esperienze di traduzione, Milano

Bompiani R.C.S. Libri Spa. [Dizer quase a mesma coisa sobre tradução, trad. José Colaço Barreiros, Lisboa, DIFEL, 2005.]

EURIPIDES (1996), As troianas, introdução, tradução e notas de Maria Helena da Rocha Pereira, Lisboa, Clássicos Gregos e Latinos, Ediçōes 70.

LEFEVERE, André (1995), "Introduction: Comparative Literature and Translation", in

Comparative Literature, Vol. 47, n. ${ }^{\circ} 1$, Winter

MONGE, João (2012), Chão de água, texto policopiado, gentilmente facultado pelo Teatro da Terra (Ponte de Sor).

MORAIS, Carlos Manuel (coord.) (2001), Máscaras portuguesas de Antigona, Aveiro, Universidade de Aveiro, Ágora, Suplemento 1; artigo consultado in <http://www2.dlc.ua.pt/classicos/Cronologia.pdf> [data de acesso: 4 de Maio de 2013].

OLIVIER, Aurélie (2009), Bain de larmes, 15 de Outubro; artigo consultado in <http://voir.ca/fiches/scene/troyennes-les/> [data de acesso: 3 de Maio de 2013]. PAVIS, Patrice (2002), Dictionnaire du théâtre, preface de Anne Ubersfeld, edition revue et corrigée, Paris, Armand Colin. 